\title{
THE EFFECT OF CAPITAL INTENSITY, EXECUTIVE CHARACTERISTICS, AND SALES GROWTH ON TAX AVOIDANCE
}

\author{
Levana Dhia Prawati ${ }^{1}$; Jesica Pinta Uli Hutagalung ${ }^{2}$ \\ Accounting Department, Faculty of Economics and Communication, Universitas Bina Nusantara \\ Jl. K.H. Syahdan No. 9, Kemanggisan, Jakarta, 021 - 534 5830, Indonesia \\ 1levana.prawati@binus.edu; ${ }^{2}$ jesicahutagalung@gmail.com
}

Received: $12^{\text {th }}$ September 2019 / Revised: $6^{\text {rd }}$ December 2019/ Accepted: $7^{\text {th }}$ March 2020

\begin{abstract}
This study aims to examine and obtain empirical evidence about the effect of capital intensity, executive character, and sales growth on tax avoidance in Indonesia public listed consumer goods industry companies over the period of 2016-2018. Using a purposive sampling method, the sample selected in this study is 30 companies. This study uses multiple linear regression analyses to examine the effect of independent variables on the dependent variable. This study shows that capital intensity and executive characteristics have significant effects on tax avoidance. Meanwhile, sales growth has no significant effect on tax avoidance.
\end{abstract}

Keywords: tax avoidance, capital intensity, executive character, sales growth

\section{INTRODUCTION}

Tax is a source of state revenue. Based on the 2018 State Budget (APBN) data obtained from the official website of the Ministry of Finance, the realization of state revenue has increased significantly. State revenue can reach Rp 1,942.3 trillion or $102.5 \%$ of the target of $\mathrm{Rp}$ 1,894.7 trillion. The biggest revenue derived from tax revenues which reached $\mathrm{Rp} 1,521.4$ trillion or $94 \%$ of the target of $\mathrm{Rp} \mathrm{1,618.1}$ trillion and an increase of $13.2 \%$ from the realization of tax revenues in 2017. The government, in this case, the Directorate General of Taxes is under the auspices of the Ministry of Finance has the responsibility to formulate and implement policies in the field of taxation considering the tax revenues in 2018 have not been able to achieve the expected targets. The Directorate General of Taxes is expected to achieve the target of annual tax revenue to maximize state revenue. One of the efforts made by the government in increasing tax revenue is the Tax Amnesty program.

According to Jamil (2017), the application of tax amnesty has not been effective until the second period. Therefore, improvements need to be made in the application of tax amnesty for the next period, for example, new policies. The government also needs to determine the initial steps to overcome and detect the problem of the wealth of Indonesian citizens who are at home and abroad to be able to determine the right policy to overcome the problem of tax avoidance in Indonesia given the large role of taxation in the country's economy.

The first factor that can affect tax avoidance is capital intensity. Research on capital intensity, empirical results conducted by Dharma and Noviari (2017) prove that capital intensity has a significant effect on tax avoidance. Dharma and Noviari (2017) state that if the intensity of fixed assets is getting bigger, then the practice of tax avoidance is also getting bigger. The company's fixed assets have different economic ages when viewed based on Indonesian taxation. Almost all fixed assets experience depreciation or depreciation and will make depreciation costs in the company's financial statements.

Depreciation costs or depreciation is meant, namely costs that can be a deduction 
from income in calculating corporate taxes. If the depreciation expense increases, the tax rate that must be paid by the company will also be smaller. If the fixed assets owned by the company are in large proportions, the tax costs paid will be lower. This is due to the benefits derived from depreciation on fixed assets that can reduce the company's tax burden.

The study is different from the results of research by Irianto, Sudibyo, and Wafirli (2017) which states that capital intensity does not have a significant effect on tax avoidance. Irianto, Sudibyo, and Wafirli (2017) in their research stated that the level of ownership of fixed assets did not provide a large enough effect in terms of reducing tax payments by companies. The high capital intensity in a company is not solely to avoid taxes but is done to run the company's operations.

The second factor that can affect tax avoidance is the executive character. Research on executive character, the empirical results conducted by Surachman (2017) prove that executive character has a significant effect on tax avoidance. Surachman (2017) in his research stated that the results of partial testing showed that executive characteristics have a significant influence on tax avoidance. Tax avoidance by companies cannot be separated from the role of a leader or executive in a decision-making process. Decision-makers must have certain characters. Executives who dare to take risks will tend to practice tax avoidance.

Meanwhile, the research is inversely proportional to the results of Kartana and Wulandari's research (2018), which states that the executive character does not have a significant effect on tax avoidance. According to Kartana and Wulandari (2018), the executive character's influence on tax avoidance is not due to the large influence of the principal in corporate decision making compared to executives including in carrying out aggressive tax actions. The executive is demanded by the principal in carrying out the principal's desire to commit or not to do tax aggressive action.

The third factor that can affect tax avoidance is sales growth. Research on sales growth, empirical results conducted by Nafis, Manik, and Fatahurrazak (2018) prove that sales growth has a significant effect on tax avoidance. Nafis, Manik, and Fatahurrazak (2018) stated that companies will tend to benefit when sales growth increases. The company will avoid taxes because if profits increase, the income taxed will also increase so that the tax that must be paid by the company will also increase.

The study is not following the results of Oktaviyani and Munandar's research (2017) which states that sales growth does not have a significant effect on tax avoidance. Oktaviyani and Munandar (2017) in their research stated that the higher the sales growth of a company, the more profits would increase. Companies that generate large profits are assumed not to take tax avoidance.

The dependent variable used in this study is tax avoidance and the independent variables used in this study are capital intensity, executive character, and sales growth. Research conducted by Nafis, Manik, and Fatahurrazak (2018) included discussing the effect of capital intensity and sales growth on tax avoidance. Therefore, the researcher intends to raise back the study of the effect of capital intensity and sales growth on tax avoidance and add new independent variables that have not been discussed and become limitations in previous studies, namely the executive character as an advantage and distinguishing factor between this study and previous research.

Previous studies used research populations in manufacturing companies in the automotive, mining, property and real estate sectors. Cahyono, Andini, and Raharjo (2016) stated that based on data from the Directorate General of Taxes, 4,000 companies were reporting zero taxes because the company suffered losses, and most were in manufacturing companies. Therefore, the researcher intends to re-examine manufacturing companies in other sectors as a distinguishing factor between this research and previous research.

The population used in manufacturing companies in the consumer goods industry sector.

The difference between this research and previous research can also be seen from the year of observation. This study uses the latest three years of observation, namely the 2016-2018 period. This research is the latest compared to research conducted by previous researchers, which is only until 2016. While this study was conducted until 2018. The results of this study are expected to be a reference for further research. 
Based on the background of the research described earlier, the issues that will be discussed in this study are as follows:

1. Does capital intensity have a significant effect on tax avoidance in the manufacturing companies in the consumer goods industry sector which are listed on the Indonesia Stock Exchange from 2016 through 2018?

2. Does the executive character have a significant effect on tax avoidance in the consumer goods manufacturing sector manufacturing companies listed on the Indonesia Stock Exchange from 2016 through 2018 ?

3. Does sales growth have a significant effect on tax avoidance in the manufacturing companies in the consumer goods industry sector which are listed on the Indonesia Stock Exchange from 2016 through 2018?

Based on the identification of the problems previously described, the objectives of this study are as follows:

1. To test and obtain empirical evidence regarding the effect of capital intensity on tax avoidance in the manufacturing companies in the consumer goods industry sector which is listed on the Indonesia Stock Exchange from 2016 through 2018.

2. To test and obtain empirical evidence regarding the effect of executive character on tax avoidance in companies manufacturing consumer goods sectors listed on the Indonesia Stock Exchange from 2016 through 2018.

3. To test and obtain empirical evidence regarding the effect of sales growth on tax avoidance in manufacturing companies in the consumer goods industry sector which is listed on the Indonesia Stock Exchange from 2016 through 2018.

\section{METHODS}

The research method used in this study is quantitative. The population used in this study is manufacturing companies that are in the consumer goods industry sector which are listed on the Indonesia Stock Exchange for 3 (three) years of observation, namely the period 20162018. The sample used in this study is the number of several characteristics in determining the sample based on the purposive sampling method. The characteristics used to determine the number of research samples are as follows:

1. Manufacturing companies in the consumer goods industry sector which are listed on the Indonesia Stock Exchange.

2. The company issued and published the company's financial statements during the 2016-2018 period.

3. Companies that have fixed assets, profits, and sales during the 2016-2018 period.

The data analysis method in this research uses multiple linear regression analysis methods. The results of the analysis are stated in the multiple linear regression equation models as follows:

\begin{tabular}{|c|c|}
\hline \multicolumn{2}{|c|}{$Y=\alpha+\beta_{1} X_{1}+\beta_{2} X_{2}+\beta_{3} X_{3}+\varepsilon$} \\
\hline $\mathrm{Y}$ & : Tax Avoidance \\
\hline$\alpha$ & : Constants \\
\hline $\mathrm{X} 1$ & : Capital Intensity \\
\hline $\mathrm{X} 2$ & : Executive Character \\
\hline $\mathrm{X} 3$ & : Sales Growth \\
\hline$\beta 1-\beta 3$ & $\begin{array}{l}: \text { Variable Regression } \\
\text { Coefficient }\end{array}$ \\
\hline$\varepsilon:$ & : Error \\
\hline
\end{tabular}

Types and sources of data used in this study are secondary data. Secondary data in this study were obtained from the financial statements of manufacturing companies in the consumer goods industry sector which are listed on the Indonesia Stock Exchange. The data used in this study is accessed through the official website page www.idx.co.id which is owned by the Indonesia Stock Exchange. The data collection method in this study uses the method of documentation and literature study. The method of presenting data in this study was processed using the software. The calculated variables will be processed using the IBM SPSS Statistics 25 program to perform various statistical tests. The statistical test method used in this study uses the following tests:

1. Descriptive Statistics Testing

2. Classical Assumption Testing

3. Hypothesis Testing 
Dyreng, Hanlon, and Maydew (2008) stated that tax avoidance can be calculated using the company's Cash Effective Tax Rate (CETR) ratio. Measurement of tax avoidance using Cash Effective Tax Rate is good to be used to describe tax avoidance activities by companies because the Cash Effective Tax Rate is not affected by changes in estimates, such as tax protection. If the value of the Cash Effective Tax Rate is getting smaller, the tax avoidance will be even greater. If the value of the Cash Effective Tax Rate is greater, tax avoidance will be smaller.

According to Gupta and Newberry (1997), capital intensity can be measured using a fixed asset intensity ratio. The ratio of the intensity of fixed assets is net property, plant, and equipment or net fixed assets to the total assets of the company. The relationship between taxation and investment selection in the form of fixed assets is in terms of depreciation. The company decided to invest in fixed assets to make the depreciation expense a deductible expense from income and be allowed to tax.

Low (2006) states the ratio used to calculate the executive character included in the risk-taker or risk-averse character, the RISK ratio. The RISK ratio is a standard deviation or deviation from income before interest, taxes, depreciation, and amortization (EBITDA) divided by the total assets of the company. The level of company risk indicates the executive character is included in the risk-taker or risk averse.

Kasmir (2011) suggested that sales growth can be measured using the ratio of Sales Growth ratio. The Sales Growth Ratio aims to show the difference between sales in the current year and sales in the previous year and then compared to sales in the previous year. A high level of sales causes company profits to increase. If sales growth is high, the tax burden that must be paid also increases. Therefore, companies tend to try to reduce the tax burden by taking tax avoidance measures.

\section{RESULT AND DISCUSSION}

Descriptive statistical tests describe the mean, standard deviation, maximum value, and minimum value.
Table 1 Descriptive Statistics Test

\begin{tabular}{cccccc}
\hline \multicolumn{5}{c}{ Descriptive Statistics } \\
\hline & $N$ & Min & Max & Mean & $\begin{array}{l}\text { Std } \\
\text { Dev }\end{array}$ \\
\hline$Y$ & 30 &, 2082 &, 3576 &, 2633 &, 0399 \\
$X_{1}$ & 30 &, 0591 &, 4831 &, 3008 &, 1245 \\
$X_{2}$ & 30 &, 0097 &, 1404 &, 0650 &, 0342 \\
$X_{3}$ & 30 &,- 004 &, 2382 &, 0794 &, 0562 \\
\hline
\end{tabular}

Tax avoidance is measured using the Cash ETR ratio. The minimum CETR value is 0.2082 for PT Siantar Top Tbk. and the maximum CETR value is 0.3576 for PT Indofood CBP Sukses Makmur Tbk. The mean value is CETR 0.2633 and the CETR standard deviation value is 0.0399 .

Capital intensity is measured using the ratio of fixed assets intensity. The minimum fixed asset intensity value is 0.0591 at PT Delta Djakarta Tbk. and the maximum fixed asset intensity value is 0.4831 at PT Pyridam Farma Tbk. The mean value of fixed assets intensity is 0.3008 and the value of standard deviation fixed assets intensity is 0.1245 .

Executive character is measured using the RISK ratio. The minimum value of RISK is 0.0097 at PT Pyridam Farma Tbk and the maximum value of RISK is 0.1404 at PT HM Sampoerna Tbk. The mean RISK value is 0.0650 and the RISK standard deviation value is 0.0342 .

Sales growth is measured using the ratio of sales growth. The minimum value of sales growth of -0.0040 at PT Pyridam Farma Tbk and the maximum value of sales growth of 0.2382 at PT Mayora Indah Tbk. The mean sales growth value is 0.0794 and the standard deviation sales growth value is 0.0562 .

Kolmogorov-Smirnov (K-S) nonparametric statistical test after removing the outlier illustrates the significance value of $0.200>0.05$. This shows that the data can be distributed normally.

In the multicollinearity test, fixed assets intensity has a tolerance value of $0.433>0.1$ and a VIF value of $2.310<10$. RISK has a tolerance value of $0.450>0.1$ and a VIF value of 2.224 $<10$. Sales growth has a tolerance value of 0.905 and a VIF value of $1.105<10$. All tolerance values $>0.1$ and all VIF values $<10$. This shows 
that there are no symptoms of multicollinearity in the regression model.

Scatterplot graphs use predictive values (ZPRED) and residual values (SRESID). Scatterplot graphs depict data or points spread above and below the number 0 on the $\mathrm{Y}$-axis. This shows that there is no symptom of heteroscedasticity. Glejser test uses regression between independent variables and absolute residual values. Glejser test illustrates the significance value of fixed assets intensity of 0.122 , RISK of 0.089 , and sales growth of 0.096. All significance values $>0.05$. This shows that there are no symptoms of heteroscedasticity.

The t-test statistic is used to test the significance of the independent variable on the dependent variable individually (partial). Tests carried out with a significance level of 0.05 ( $\alpha$ $=5 \%)$.

Table 2 t-test Statistics

\begin{tabular}{cccccc}
\hline \multicolumn{6}{c}{ Coefficients } \\
\hline \multicolumn{7}{c}{$B$} & $\begin{array}{c}\text { Std. } \\
\text { Error }\end{array}$ & Beta & $t$ & Sig. \\
\hline & & & & & \\
$\alpha$ &, 411 &, 043 & & 9,5 &, 000 \\
$X_{1}$ &,- 251 &, 078 &,- 782 & $-3,2$ &, 003 \\
$X_{2}$ &,- 977 &, 278 &,- 838 & $-3,5$ &, 002 \\
$X_{3}$ &,- 110 &, 119 &,- 156 &,- 92 &, 362 \\
\hline
\end{tabular}

Based on the results of the $t$ statistical test, the $t$-table value of the $t$ table distribution value is 2.05553 with $\alpha / 2=0.025$ and df $(\mathrm{n}-\mathrm{k}-1)=$ 26. The t-value of fixed assets intensity is $3,223>-2,05553$ and the calculated RISK tvalue of $-3.518>-2.05553$. This shows that $\mathrm{H} 1$ and $\mathrm{H} 2$ are accepted because the variable fixed assets intensity and RISK variables partially influence the Cash ETR variable.

However, the t-value of sales growth is $0,927<-2,05553$. This shows that $\mathrm{H} 3$ is rejected because the sales growth variable does not partially affect the Cash ETR variable.

Interpretation of the results of the regression equation previously described is as follows:
The test results partially the effect of each independent variable on the dependent variable obtained as follows:

1. A constant value of 0.411 indicates that if the fixed asset intensity (X1), RISK (X2) and sales growth (X3) variables are equal to zero, the Cash ETR (Y) value is 0.411 or $41.1 \%$.

2. The fixed assets intensity coefficient value is -0.251 . This shows that for every $1 \%$ increase in the variable fixed assets intensity assuming other variables are fixed, the Cash ETR variable will decrease by 0.251 or $25.1 \%$.

3. RISK coefficient value of -0.977 . This shows that for every $1 \%$ increase in the RISK variable, assuming the other variables are fixed, the Cash ETR variable will decrease by 0.977 or $97.7 \%$.

4. Sales growth coefficient value of 0,110 . This shows that for every $1 \%$ increase in sales variable assuming other variables are fixed, the Cash ETR variable will decrease by 0.110 or $11 \%$.

F statistical test aims to determine whether all independent variables together affect the dependent variable. $\mathrm{H} 0$ tests all parameters in the model equal to zero, meaning that all independent variables are not a significant explanation of the dependent variable. Meanwhile, Ha tests not all parameters simultaneously equal to zero, meaning that all independent variables simultaneously are a significant explanation of the dependent variable.

Table 3 F - Test Statistics

\begin{tabular}{lcc}
\hline \multicolumn{2}{c}{ ANOVA $^{a}$} \\
\hline Model & $F$ & Sig. \\
\hline Regression 4,409 & $012^{\mathrm{b}}$ \\
Residual & \\
Total & \\
\hline a. Dependent & Variable: Cash ETR \\
b. Predictors:(Constant), Sales Growth, \\
RISK, Fixed Assets Intensity \\
\hline
\end{tabular}

Based on the results of the $F$ statistical test, the $\mathrm{F}$ value of $4.409>4$. This shows that $\mathrm{H} 1, \mathrm{H} 2$, 
and $\mathrm{H} 3$ are accepted because all independent variables simultaneously have a significant effect on the dependent variable. The F-table value in the F-table distribution table is 2.96 with $\mathrm{k}=3$ and $\mathrm{df}(\mathrm{n}-\mathrm{k})=27$. The F-count value is 4.409> 2.96. This shows that $\mathrm{H} 0$ is accepted and $\mathrm{H} 1, \mathrm{H} 2$, and $\mathrm{H} 3$ are accepted because all independent variables simultaneously and significantly affect the dependent variable.

The coefficient of determination statistical test aims to measure how far the model's ability to explain the dependent variable. If the value of R2 is small, the ability of the independent variables in explaining the dependent variable is limited. If the value of R2 is large, then the independent variables provide almost all the information needed by the dependent variable.

The statistical test of the coefficient of determination (R2) uses the Summary Model table as follows.

Table 4 Determination Coefficient Test

\begin{tabular}{|c|c|c|c|}
\hline \multicolumn{4}{|c|}{ Model Summary ${ }^{b}$} \\
\hline$R$ & $R^{2}$ & Adjusted $R^{2}$ & $\begin{array}{c}\text { Std. } \\
\text { Error }\end{array}$ \\
\hline, $581^{\mathrm{a}}$ & ,337 & ,261 & ,0343 \\
\hline a. $\quad P$ & \multicolumn{3}{|c|}{$\begin{array}{l}\text { Predictors: (Constant), Sales Growth, } \\
\text { RISK, Fixed Assets Intensity } \\
\text { Dependent Variable: Cash ETR }\end{array}$} \\
\hline
\end{tabular}

Based on the results of the coefficient of determination test, the value of $\mathrm{R}$ Square of 0.337 . This shows that the independent variables in this study simultaneously have a significant effect on the dependent variable of $33.7 \%$. Meanwhile, the remaining $66.3 \%$ is explained by other factors besides the independent variables in this study.

The results of the study indicate that capital intensity can influence the practice of tax avoidance. Every company wants high income, but the company also seeks to minimize tax payments. Capital intensity is measured by comparing the number of fixed assets owned by the company against the total assets of the company. The choice of investment in the form of fixed assets is used by companies to reduce taxation costs. Fixed assets have depreciation costs that can be used as a deduction from taxable income so that the depreciation costs obtained from these assets can reduce the company's tax burden. Thus, the desire of the company to maximize revenue and minimize tax payments will be achieved. The greater the number of fixed assets owned by the company, the greater the cost of depreciation. If the depreciation expense gets bigger, the amount of taxable income will decrease. This study is in line with research conducted by Dharma and Noviari (2017) which proves that capital intensity has a significant effect on tax avoidance.

The results indicate that the executive character can influence the practice of tax avoidance. The role of the executive is very important in the company's decision-making process. Every decision has its risks. The executive character who is bolder generally has a strong desire to earn as much as possible. However, high-income results in high tax payments. This is not desired by the company and causes executives to try to minimize the cost of taxation by taking tax avoidance measures. This study is in line with research conducted by Surachman (2017) which proves that executive character has a significant effect on tax avoidance.

The results indicate that sales growth cannot affect tax avoidance. The level of sales growth can reflect the productivity of the company and can be used to predict future sales growth. The higher the level of sales growth, the higher the company's profit. The belief that a company can pay its taxation costs does not affect tax avoidance due to an increase in profits earned. This study is not following research conducted by Nafis, Manik, and Fatahurrazak (2018) which proves that sales growth has a significant effect on tax avoidance. However, this research is in line with research conducted by Oktaviyani and Munandar (2017) which proves that sales growth has no significant effect on tax avoidance.

\section{CONCLUSION}

Based on the results of tests and previous discussions, this study can be concluded as follows:

1. The first hypothesis, namely capital intensity influences tax avoidance. The first hypothesis $\left(\mathrm{H}_{1}\right)$ is accepted because the variable fixed assets intensity affects the Cash ETR variable partially. 
2. The second hypothesis, namely the executive character influences tax avoidance. The second hypothesis $\left(\mathrm{H}_{2}\right)$ is accepted because the RISK variable partially influences the Cash ETR variable.

3. The third hypothesis, namely sales growth influences tax avoidance. The third hypothesis $\left(\mathrm{H}_{3}\right)$ is rejected because the sales growth variable has no partial effect on the Cash ETR variable.

4. The first hypothesis $\left(\mathrm{H}_{1}\right)$, the second hypothesis $\left(\mathrm{H}_{2}\right)$, and the third hypothesis $\left(\mathrm{H}_{3}\right)$ are accepted simultaneously because all the independent variables, namely capital intensity, executive character, and sales growth significantly influence the dependent variable, namely tax avoidance.

The limitations possessed by the author in conducting this research include the following:

1. This study uses a research sample for 3 (three) years of observation, namely the 2016-2018 period so that it cannot yet describe the company's behavior towards long-term tax avoidance measures.

2. This research was conducted on companies registered in one sector of manufacturing companies, namely companies in the consumer goods industry sector so that it has not described tax avoidance measures on all manufacturing companies.

3. This study uses a proxy for calculating tax avoidance, namely Cash ETR so that there are still other proxies that have not been used to measure tax avoidance.

4. This study uses independent variables that affect the dependent variable simultaneously by $33.7 \%$ so that there are still other factors besides the independent variables in this study amounting to $66.3 \%$ which have not been used and can explain the dependent variable.

Suggestions that can be given in connection with the results of this study are as follows:
1. For further researchers, it is recommended to use a research sample by adding years of observation or other independent variables and using other proxies to measure tax avoidance.

2. For company management, it is advisable to consider implementing proper tax avoidance practices without harming the state and following applicable tax regulations and including the previous year's financial statements after the turn of the year on the official website of the Indonesia Stock Exchange to facilitate the users of financial statement information.

3. For investors, it is advisable to pay attention to the tendencies of companies that enable the implementation of tax avoidance practices, especially in manufacturing companies in the consumer goods industry sector.

4. For regulators, it is advisable to pay attention to the use of loopholes that can be used by companies in implementing tax avoidance practices that can harm the country so that it can make tax regulations that are getting better in the future.

\section{REFERENCES}

Cahyono, D. D., Andini, R., Raharjo, K. (2016). Pengaruh Komite Audit, Kepemilikan Institusional, Dewan Komisaris, Ukuran Perusahaan (SIZE), Leverage (DER) Dan Profitabilitas (ROA) Terhadap Tindakan Penghindaran Pajak (Tax Avoidance) Pada Perusahaan Perbankan Yang Listing BEI Periode Tahun 2011-2013. Journal Of Accounting, vol. 2, no. 2.

Dharma, N. B. S., Noviari, N. (2017). Pengaruh Corporate Social Responsibility dan Capital Intensity terhadap Tax Avoidance. E-Jurnal Akuntansi Universitas Udayana, vol. 18 , no. 1.

Dyreng, S, Hanlon, M., Maydew, E. (2008). Long Run Corporate Tax Avoidance. The Accounting Review, vol. 83. no. 1, pp. 6182. 
Gupta, S., Newberry, K. (1997). Determinants of the Variability on Corporate Effective Tax Rates: Evidence from Longitudinal Data. Journal of Accounting and Public Policy, vol. 16, no. 1, pp. 1-34.

Irianto, B. S., Sudibyo, Y. A., Wafirli, A. (2017). The Influence of Profitability, Leverage, Firm Size and Capital Intensity Towards Tax Avoidance. International Journal of Accounting and Taxation, vol. 5, no. 2, pp. 33-41.

Jamil, N. A. (2017). Efektivitas Penerapan Tax Amnesty di Indonesia. Journal of Multidisciplinary Studies, vol. 1, no. 1.

Kartana, I. W., Wulandari, N. G. A. S. (2018). Pengaruh Karakter Eksekutif, Karakter Perusahaan, dan Corporate Governance terhadap Tax Avoidance. Jurnal KRISNA: Kumpulan Riset Akuntansi, vol. 10, no. 1.

Kasmir. (2011). Analisis Laporan Keuangan. Jakarta: PT. Rajagrafindo Persada.

Low, A. (2006). Managerial Risk-Taking Behavior and Equity-Based
Compensation. Fisher College of Business Working Paper.

Nafis, M., Manik, T., Fatahurrazak. (2018). Pengaruh Return on Asset (ROA), Capital Intensity, Sales Growth, Debt to Asset Ratio (DAR), dan Firm Size terhadap Penghindaran Pajak (Tax Avoidance) pada Perusahaan Manufaktur yang Terdaftar di Bursa Efek Indonesia Periode 2012-2016. Repository Umrah.

Oktaviyani, R., Munandar, A. (2017). Effect of Solvency, Sales Growth, and Institutional Ownership on Tax Avoidance with Profitability as Moderating Variables in Indonesian Property and Real Estate Companies. Binus Business Review, vol. 8, no. 3, pp. 183-188.

Surachman, A. E. (2017). Influence of Executive Characteristics and Duality of Chief Executive Officer to Tax Avoidance. International Journal of Science and Research (IJSR), vol. 6. 